\title{
PESTICIDE APPLICATION WINDOWS IN THE REGION OF UBERLÂNDIA- MG, BRAZIL
}

\author{
JANELAS DE APLICAÇÃO DE PRODUTOS FITOSSANITÁRIOS NA REGIÃO DE \\ UBERLÂNDIA-MG, BRASIL
}

\author{
João Paulo Arantes Rodrigues da CUNHA ${ }^{1}$; Júlia Nunes Paniago PEREIRA²; \\ Lucas Andrade BARBOSA ${ }^{3}$; Cláudio Ricardo da SILVA ${ }^{4}$ \\ 1. Professor, Instituto de Ciências Agrárias - ICIAG, Universidade Federal de Uberlândia - UFU, Uberlândia, MG, Brazil. \\ jpcunha@iciag.ufu.br; 2. Undergraduate student, ICIAG - UFU, Uberlândia, MG, Brazil; 3. Graduate student, ICIAG - UFU, \\ Uberlândia, MG, Brazil; 3. Professor, ICIAG - UFU, Uberlândia, MG, Brazil.
}

\begin{abstract}
The success of the pesticide application is subject to meteorological conditions. The objective of this work was to determine the application windows suitable for carrying out the application of pesticides, using as parameters the analysis of historical data (2009-2014) of air temperature, relative air humidity, wind speed, and rainfall of Uberlândia-MG. With an electronic spreadsheet, and using the ideal meteorological conditions for applying pesticides (an air temperature above $30^{\circ} \mathrm{C}$, relative air humidity above $55 \%$, wind speed between 3 and $12 \mathrm{~km} \mathrm{~h}^{-1}$, and rainfall data lower than $0.2 \mathrm{~mm} \mathrm{~h}^{-1}$ ) as a parameter, the data were crossed with the aim to determine the times of day that weather conditions were ideal to obtain better efficiency in the application. According to the results, the relative air humidity was the main restricting criterion for the application windows, which are concentrated, on average, between 18:00 and 12:00 in the summer, and between 24:00 and 9:00 in the winter. The number of viable hours for a good application varied from 35 in the first fortnight of September to 198 in the second fortnight of March, demonstrating the great variability among the application windows throughout the year, which makes the generic recommendations of spraying time inadequate if the month of the year is not taken into consideration.
\end{abstract}

KEYWORDS: Application technology. Spray. Weather conditions.

\section{INTRODUCTION}

In the current agricultural production model, the pesticide application is indispensable for most crops, with the intent of controlling pests, disease, and weeds. The applications aim to preserve the genetic potential of the plants and, consequently, to ensure high yields. However, in order to obtain success in an application it is necessary to consider various issues linked to application technology, among them weather conditions.

The air temperature and relative air humidity have a direct effect on the evaporation of the sprayed droplets, thus, it is recommended that operations be avoided when temperatures are above $30^{\circ} \mathrm{C}$ and relative air humidity is below $55 \%$ Wind speed directly influences the drift of the droplets, and ideally applications should be carried out with winds of up to $12 \mathrm{~km} \mathrm{~h}^{-1}$ in a constant direction. Wind speeds above $12 \mathrm{~km} \mathrm{~h}^{-1}$ run a greater risk of loss due to spray drift (MINGUELA; CUNHA, 2010).

According to Murphy et al. (2000), pesticide drift is characterized by path deviation of the liquid particles of the application, being influenced by, among other things, wind speed, boom height, displacement speed of the applicator equipment, and the size of the droplets. This is considered one of the greatest problems of modern agriculture. Fine droplets are more highly recommended when it comes to depositing the product on the target, providing better control results, however, this can bring about loss by evaporation and drift (NUYTTENS et al., 2011).

When dealing with weather condition, it is important to note that the absence of wind can also be harmful as it complicates the deposition of small droplets due to rising warm air. The early morning and late afternoon are periods where the relative air humidity is higher and the air temperature is lower and are therefore considered the most suitable intervals for the applications (ANTUNIASSI, 2005).

Rainfall and dew are also meteorological factors of great importance in the planning of applications. With regards to rain, one must observe the minimum time interval between rainfall and application, seeking to allow an adequate period for the action of the products. In the case of dew, the presence of water on the leaves when the applications occur in the night period and or/ the early morning can interfere with the application technique. In this case, the product may be diluted and eventually run due to the excess water and the action of the surfactants contained in the solutions (ANTUNIASSI, 2005). 
Therefore, considering the meteorological variables, the applications should be performed while giving priority to wind speed, average temperature, and recommended relative humidity, thus minimizing the problems caused by product drift and allowing the grower success in spraying. In this sense, Nuyttens et al. (2006) verifies, in a study about the occurrence of drift in boom sprayers, that increases in relative air humidity, decreases in wind speed, and decreases in air temperature result in a reduction in drift and, consequently, in a greater benefit from the applied product.

However, a different scenario is seen in the field in which the applications are made throughout the day, without respect to suitable climatic conditions. In general, this occurs because of inadequate operational planning. In the moment that one acquires the machinery, one does not know the operational windows throughout the year, thus there is no technical aid for determining the real necessity of the operational ability of the sprayers. Few studies exist in literature about the subject, which further worsens the situation. According to Hertz et al. (2004), an application window refers to the suitable periods for an effective application.

The variability of the atmospheric conditions brings with it uncertainties in setting up necessary equipment. These setting options serve either to prepare the mechanized units to address the most critical conditions, which consequently brings about the under utilization of the machinery and an increase in the proprietary costs, or to prepare the fleet for normal years, reducing the investment and increasing the return, but also increasing the risk of crop loss due to the operation being performed outside of the stipulated parameters or due to a fall in the quality of the product (MILAN, 2004).

In this context, the region of Uberlândia in the Triangulo Mineiro is inserted. The region is among those that present notable relevance in the agricultural scenario, however there have not yet been many studies concerning meteorological factors and, in comparison with other regions, the data made available by the meteorological stations is still limited (SILVA et al., 2008).

Thus, the objective of this work was to determine the application windows suitable for conducting pesticide application, using as parameters the analysis of historical data on air temperature, air humidity, wind speed, and rainfall for the region of Uberlândia-MG.

\section{MATERIAL AND METHODS}

The work was conducted through the analysis of historical data schedules of the meteorological variables air temperature $\left({ }^{\circ} \mathrm{C}\right)$, air humidity $(\%)$, rainfall $(\mathrm{mm})$, and wind speed $\left(\mathrm{km} \mathrm{h}^{-}\right.$ ${ }^{1}$ ), in the period composed of the years 2009 to 2014 (6 years). The data was made available by automated meteorological station A507 (code OMM: 86776) belonging to the Instituto Nacional de Meteorologia (INMET). The automated station is located in Uberlândia at the Instituto de Geografia of the Federal University of Uberlândia (UFU), coordinates $-18.917072^{\circ} \mathrm{S}$ and $-48.255657^{\circ} \mathrm{WG}$ and an altitude of $875 \mathrm{~m}$ (INMET, 2015).

Uberlândia has a hot humid tropical climate with a cold dry winter represented by the symbol Aw according to the Köppen classification (SILVA et al., 2008). The region presents an average annual rainfall which varies between 1500 and $1600 \mathrm{~mm}$, $50 \%$ of which occurred in the months of December to February, characterizing the summer season. The total monthly average that represents the greatest amount of rainfall is approximately $250 \mathrm{~mm}$, and the smallest amount is about $60 \mathrm{~mm}$ (SILVA et al., 2008). In the summer season, which contains the hottest months of the year, the average monthly high air temperatures are in the range of $21^{\circ} \mathrm{C}$ to $26^{\circ} \mathrm{C}$, while in the winter period the registered monthly averages are between $17^{\circ} \mathrm{C}$ and $22^{\circ} \mathrm{C}$, annually the air average temperatures are in the range of $20^{\circ} \mathrm{C}$ to $25^{\circ} \mathrm{C}$ (ROSA; SCHIAVINI, 2006). The relative air humidity presents a certain variation throughout the year, increasing with the start of the rains and decreasing with the arrival of the dry season, the yearly averages fall around $70 \%$ to $75 \%$ (ROSA; SCHIAVINI, 2006), albeit during the winter the values are much lower.

The acquisition of the historical variables data was made at INMET website (http://www.inmet.gov.br), from the month of January of 2009 to the month of December of 2014. The data was tabulated in an electronic spreadsheet (Excel®), and the sequence succeeded the daily verification of the consistency of the available information. On the days that the information was inconsistent or when a variable was missing, the data was eliminated. After the transformation of the maximum and minimum values of air temperature and humidity into hourly averages was performed, and also, a unit conversion from meters per second $\left(\mathrm{m} \mathrm{s}^{-1}\right)$ to kilometers per hour $\left(\mathrm{km} \mathrm{h}^{-1}\right)$ was done for the variable wind speed.

With the aid of an electronic spreadsheet (Excel $\left.{ }^{\circledR}\right)$ and using a parameter the ideal meteorological conditions for conducting pesticide applications, a temperature below $30^{\circ} \mathrm{C}$, a relative 
air humidity above 55\%, wind speed between 3 and $12 \mathrm{~km} \mathrm{~h}^{-1}$ and rainfall data smaller than $0.2 \mathrm{~mm} \mathrm{~h}^{-1}$ (ANDEF, 2004; ALVARENGA et al., 2014; ANTUNIASSI, 2005), the data was crossed with aim to determine the times of day that all four weather conditions were within the intervals recommended in order to obtain better efficiency in the application. The scoring and clustering of the hours was performed in order to generate graphs and tables with fortnight and hourly analyses.

\section{RESULTS AND DISCUSSION}

In the six years, 2009 to 2014, after filtering inconsistent weather data, it was summed 33,662 $(66 \%)$ of 51,096 hours which have unfavorable conditions for the pesticides application. According to Friedrich (2004), there is a loss of the pesticide of approximately $50 \%$ due to unfavorable application conditions. Wind is responsible for the drift of the droplets into undesired areas, while the high air temperature and low air humidity accelerated the evaporation process, principally of the water present in the droplets, which causes the active ingredient to stay in very fine droplets, subject to the drift process.

The average monthly evolutions of the hourly maximum and minimum air temperature throughout the year are showed in the Figure 1. Note that, largely, the maximum air temperatures occurred in the period of 14:00 to $16: 00 \mathrm{~h}$ and the minimum air temperatures occurred between 5:00 and 7:00 $\mathrm{h}$. The greatest thermal amplitudes occurred in the months of May, June, July, and August, characteristic of winter in the southeast region of Brazil, which begins in the month of June. Due to the potential of water vapor to re-emitted terrestrial radiation to surface, during the summer months, or the rainy period, the nocturnal and diurnal air temperatures are less variable, principally with an easing of air maximum temperature due to changes in the total of the direct and diffuse components with the cloud cover (SANTOS, 2013). The highest average air temperatures were recorded in the months of September and October, when the maximum air temperature reached and surpassed $30^{\circ} \mathrm{C}$. The lowest average air temperatures were recorded in the months of May, June, and July, reaching at the highest around $27^{\circ} \mathrm{C}$.
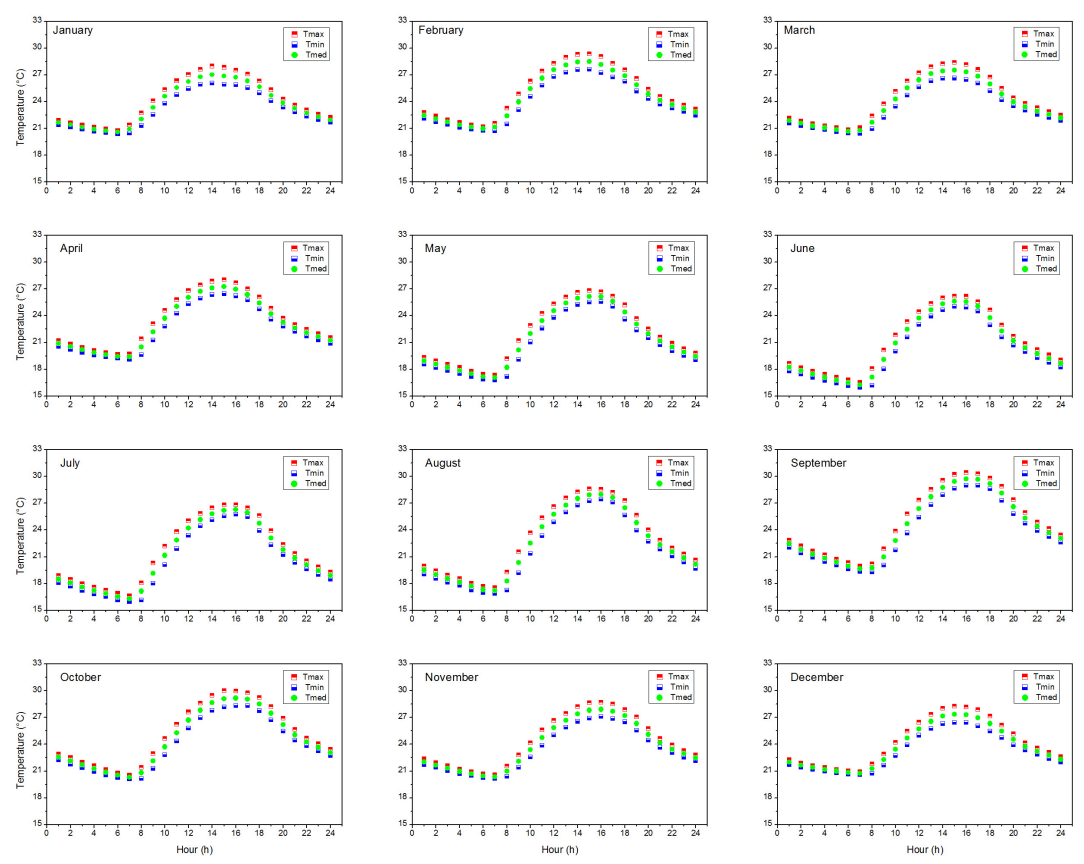

Figure 1. Monthly hourly maximum, average, and minimum air temperature $\left({ }^{\circ} \mathrm{C}\right)$ throughout the year. Uberlândia-MG, Brazil (data period: 1/2009 to 12/2014).

Throughout the Spring and Summer months, which are the usual months for the main crop, the maximum temperatures observed keeps below maximum limits for spraying $\left(30^{\circ} \mathrm{C}\right)$, with the 
exception of the months of September and October, which reached $30^{\circ} \mathrm{C}$ in the period of $14: 00$ to $18: 00$ h. In terms of air temperature, in the months of January, February, March, November, and December, the amount of time available for application throughout the day is greater, due to the lower thermal amplitudes and due to the fact that the temperature is milder when compared with the months of the dry season. In the case of the second crop (the little harvest), the pesticide application is concentrated in the months of March and June, the temperature of which is viable and tends to decrease every month, mainly in the afternoon period.

Although the air temperature conditions analyzed along of day and year could be considerably ideal for pesticide applications, the relative air humidity is a factor that would decrease the amount of viable times to carry out a good application. The low relative air humidity can result in the evaporation of pesticide and/or the water before the product can reach the target. According to Lado et al. (2007), the time of day has an important influence on the levels of relative air humidity, since in the first hours of the morning, the temperatures are lower and the relative air humidity levels are higher. Through the course of the day, the temperature tends to rise and the humidity tends to decrease. In the middle of the afternoon period, the air temperatures are at their maximum values and the relative air humidity reaches its minimum value.

In Figure 2, the monthly hourly curves of the maximum, minimum, and average relative air humidity (UR) are presented. In the winter (June, July, August, and September) and summer (December, January, February, and March), the UR levels throughout the day are quite variable, with moments in which they are found to be above 55\% and others were levels below 55\% are encountered. These differences observed between the two seasons are justified by the fact that the relative humidity is the principal indicator of the formation and/or presence of water vapor in the atmosphere, clouds, and consequently, rainfall (SANTOS, 2013). In the summer months, the times in which the minimum relative humidity is found to be lower than $55 \%$ are similar, and are typically from 13:00 to $17: 00 \mathrm{~h}$. Taking into consideration, the variables relative humidity and temperature, in the main crop season, between the months of December and March, the most beneficial hours for the effectiveness of the application are between 18:00 and 12:00 h. In the winter months, this pattern is changed, since the relative humidity is below $55 \%$ for the greater part of the day, decreasing the amount of application windows. Note that in the months of July and October, the average relative humidity is generally below the suitability benchmark between 10:00/11:00 and 21:00/22:00, and the months of August and September present low UR from around 8:00 and 3:00, thus having a very short daily window only at 5:00.

There is a general recommendation that the applications should preferably be carried out up until 10:00 or after 16:00, seeking better meteorological conditions. However, in the view of the aforementioned, note that this recommendation depends on the season. In the summer it is preferable that the applications be extended until noon and only recommence after 18:00 if necessary. In the winter, the applications should preferably be made until 9:00. This case shows that the employment of evaporation and drift reduction strategies is essential. The use of additives, for example, can help to minimize the evaporation phenomenon. This also shows that adjusting the droplet size to suit the climatic conditions is crucial, avoiding fine droplets in the times when conditions promote evaporation.

In Figure 3, the average hourly values for wind speed are shown. Note that in practically all of the months, the average values conform to the recommendations indicated for spraying (higher than $3 \mathrm{~km} \mathrm{~h}^{-1}$ and lower than $12 \mathrm{~km} \mathrm{~h}^{-1}$ ). The greatest value was recorded in the month of September between 10:00 12:00 with a wind speed that reached and briefly passed $12 \mathrm{~km} \mathrm{~h}^{-1}$ at around 11:00. The greatest and smallest nocturnal averages were recorded in August and September. Throughout the year, the diurnal wind speeds were higher than the nocturnal wind speeds, with greater intensities in the hottest hours of the day (between 9:00 and 17:00).

Analyzing the data simultaneously, the relative humidity becomes the principal restricting criterion, since the temperature is suitable most of the time, with the exception of the months September and October, when the maximum temperature was greater than or equal to $30^{\circ} \mathrm{C}$. The wind speed was between $3 \mathrm{~km} \mathrm{~h}^{-1}$ and $12 \mathrm{~km} \mathrm{~h}^{-1}$, with the greatest average value in the month of September, between 10:00 and 12:00, with unsuitable speeds around 11:00. According to the analyses of relative humidity, it follows that depending on the season, the application windows are larger in the summer and narrower in the winter. 

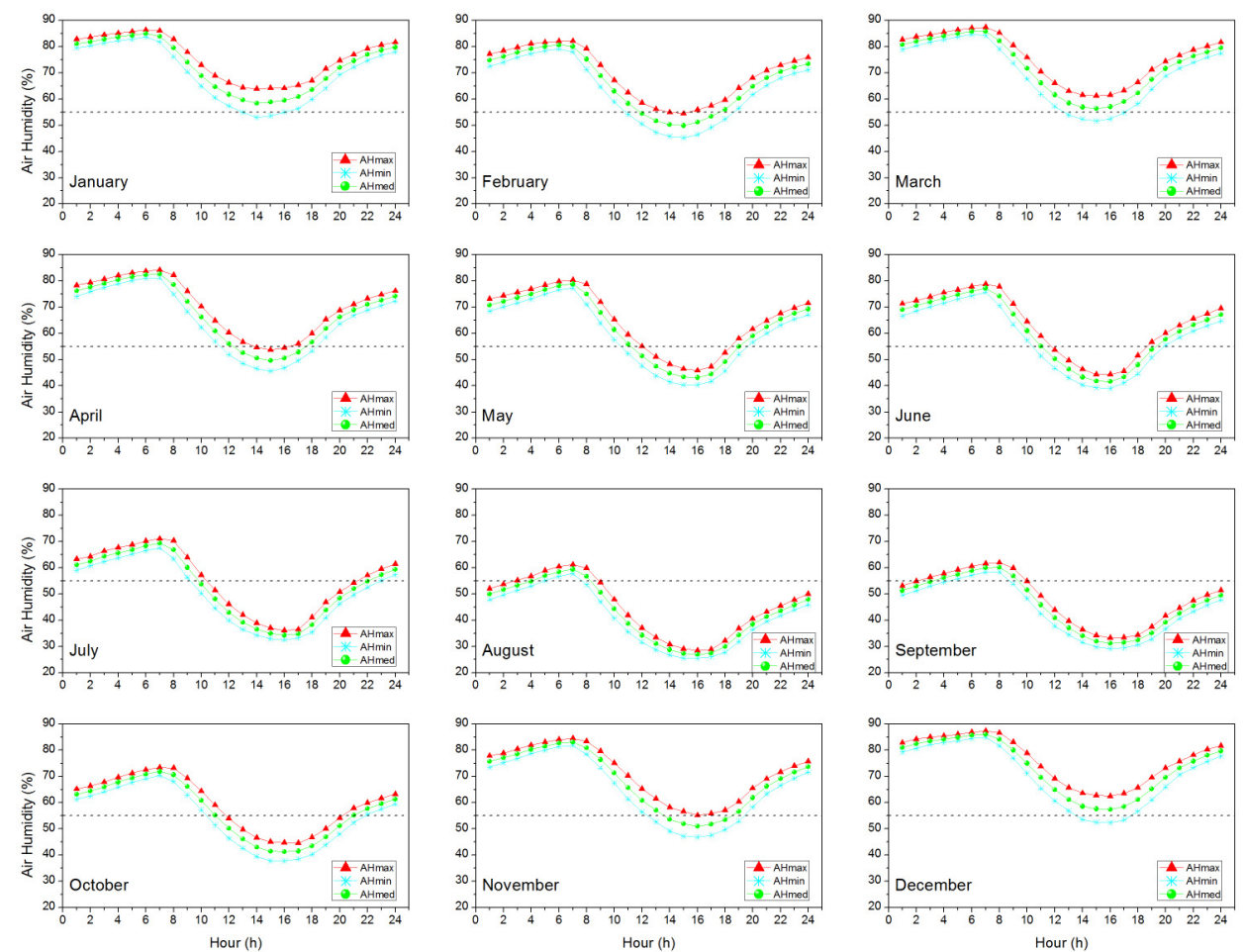

Figure 2. Monthly hourly maximum, average, and minimum relative air humidity (\%) throughout the year. Uberlândia-MG, Brazil (data period: 1/2009 to 12/2014).
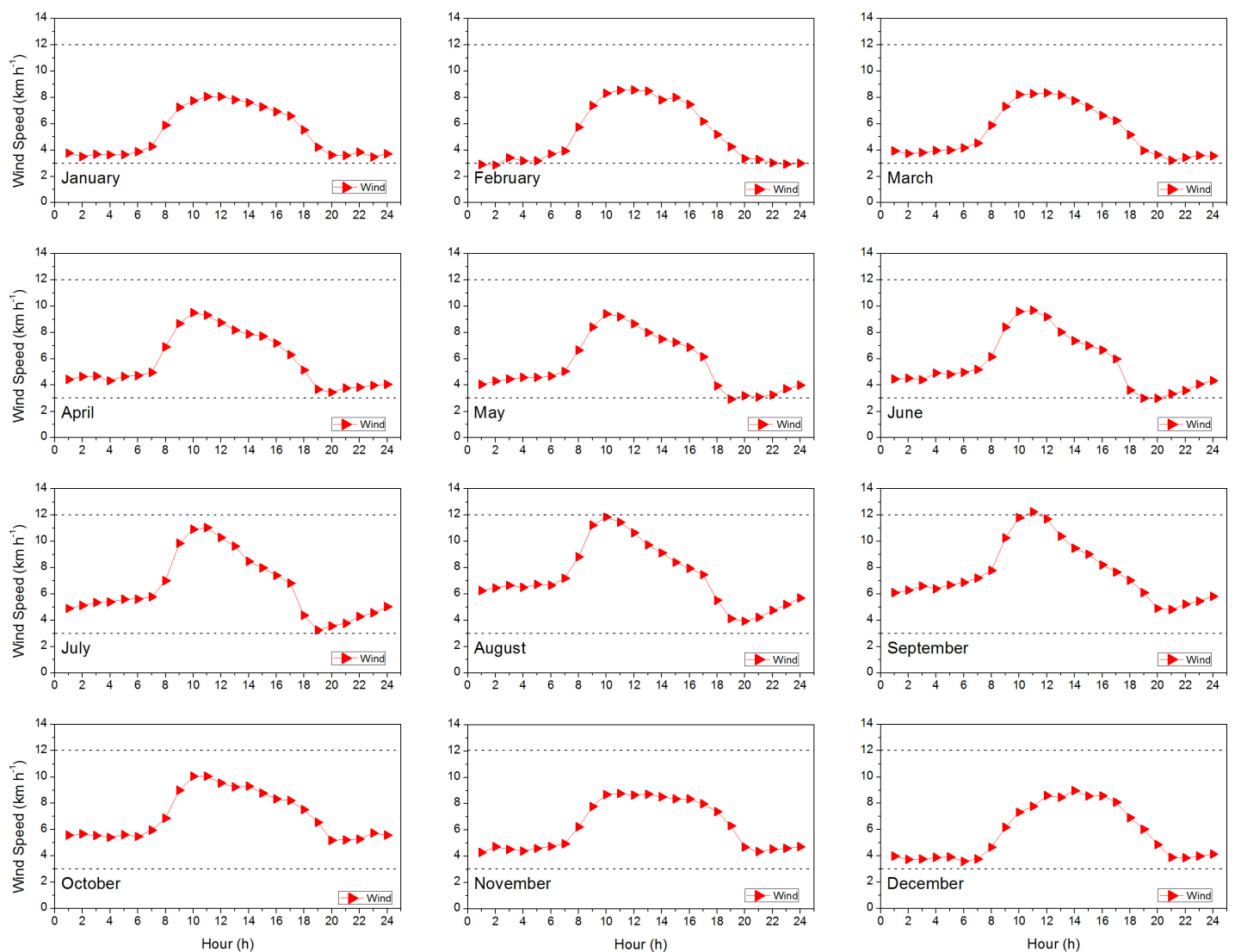

Figure 3. Average monthly hourly wind speed $\left(\mathrm{km} \mathrm{h}^{-1}\right)$ throughout the year. Uberlândia-MG, Brazil (data period: $1 / 2009$ to $12 / 2014$ ). 
Taking into account the aforementioned data (temperature, humidity, and wind speed), and excluding the unviable hours in the case of rain $\left(\right.$ rainfall $>0.2 \mathrm{~mm} \mathrm{~h}^{-1}$ ), one has Table 1 . In that same table the percentage of viable hours throughout the day is shown. Note that smallest values are concentrated between the months of July and September, and are principally associated with relative humidity, which again proves to be the most restrictive criterion. The month with the highest average percentage of viable hours $(43 \%)$ was November, and the smallest percentage was encountered in August (14\%)

Table 1. Percentage (\%) of viable hours for the pesticide application throughout the days from January to December. Uberlandia-MG, Brazil.

\begin{tabular}{ccccccccccccc}
\hline Hour & Jan & Feb & Mar & Apr & May & Jun & Jul & Aug & Sep & Oct & Nov & Dec \\
\hline 0 & 37 & 33 & 39 & 49 & 46 & 48 & 38 & 19 & 20 & 41 & 47 & 41 \\
1 & 35 & 29 & 44 & 61 & 53 & 53 & 43 & 22 & 26 & 40 & 56 & 40 \\
2 & 38 & 30 & 44 & 60 & 56 & 62 & 50 & 24 & 29 & 39 & 48 & 41 \\
3 & 39 & 35 & 45 & 64 & 55 & 59 & 52 & 25 & 27 & 41 & 54 & 43 \\
4 & 40 & 31 & 47 & 60 & 61 & 62 & 54 & 25 & 27 & 39 & 55 & 43 \\
5 & 38 & 37 & 46 & 58 & 59 & 59 & 56 & 33 & 37 & 45 & 51 & 44 \\
6 & 39 & 40 & 44 & 63 & 62 & 62 & 59 & 38 & 40 & 48 & 55 & 40 \\
7 & 52 & 42 & 47 & 63 & 60 & 64 & 62 & 43 & 37 & 47 & 62 & 56 \\
8 & 53 & 54 & 56 & 73 & 67 & 64 & 53 & 25 & 24 & 42 & 61 & 64 \\
9 & 53 & 49 & 58 & 66 & 53 & 58 & 26 & 11 & 19 & 37 & 58 & 64 \\
10 & 44 & 41 & 58 & 49 & 37 & 38 & 12 & 7 & 13 & 33 & 52 & 61 \\
11 & 44 & 34 & 54 & 38 & 30 & 21 & 7 & 4 & 9 & 23 & 42 & 47 \\
12 & 34 & 28 & 45 & 36 & 20 & 16 & 4 & 2 & 8 & 14 & 32 & 44 \\
13 & 26 & 19 & 36 & 25 & 13 & 12 & 4 & 2 & 8 & 9 & 24 & 28 \\
14 & 25 & 18 & 28 & 18 & 11 & 12 & 4 & 2 & 7 & 9 & 21 & 26 \\
15 & 22 & 17 & 28 & 19 & 11 & 12 & 3 & 1 & 7 & 9 & 18 & 23 \\
16 & 23 & 15 & 31 & 21 & 12 & 10 & 4 & 1 & 8 & 11 & 22 & 32 \\
17 & 30 & 27 & 35 & 24 & 14 & 12 & 5 & 1 & 8 & 15 & 24 & 38 \\
18 & 33 & 28 & 38 & 35 & 21 & 24 & 8 & 3 & 7 & 22 & 32 & 39 \\
19 & 38 & 36 & 41 & 34 & 26 & 24 & 11 & 5 & 10 & 28 & 36 & 44 \\
20 & 37 & 33 & 35 & 38 & 32 & 28 & 18 & 7 & 14 & 31 & 36 & 41 \\
21 & 37 & 34 & 37 & 45 & 38 & 33 & 20 & 8 & 16 & 34 & 42 & 40 \\
22 & 35 & 29 & 35 & 41 & 38 & 32 & 27 & 12 & 24 & 39 & 45 & 34 \\
23 & 35 & 28 & 43 & 46 & 44 & 45 & 37 & 17 & 24 & 39 & 47 & 46 \\
\hline
\end{tabular}

In Figure 4, the amount of viable hours in the fortnights of each month of the year is presented. Note that in the months of August and September the smallest availability of suitable hours to carry out the application was found. The highest amount of suitable hours was found in the months of November, December, January, and February. It must be emphasized that in certain years there was a sharp decrease in these hours due to the dry spells that occur when rain is scarce and consequent fall in relative humidity and rise in temperature. The forecasting of dry spells, while difficult, is highly significant for agriculture as it provides additional information for agricultural planning, for both dry and irrigated, since it can aid in the maximization of the efficient use of water in the cultivated areas (CARVALHO et al., 1999). 


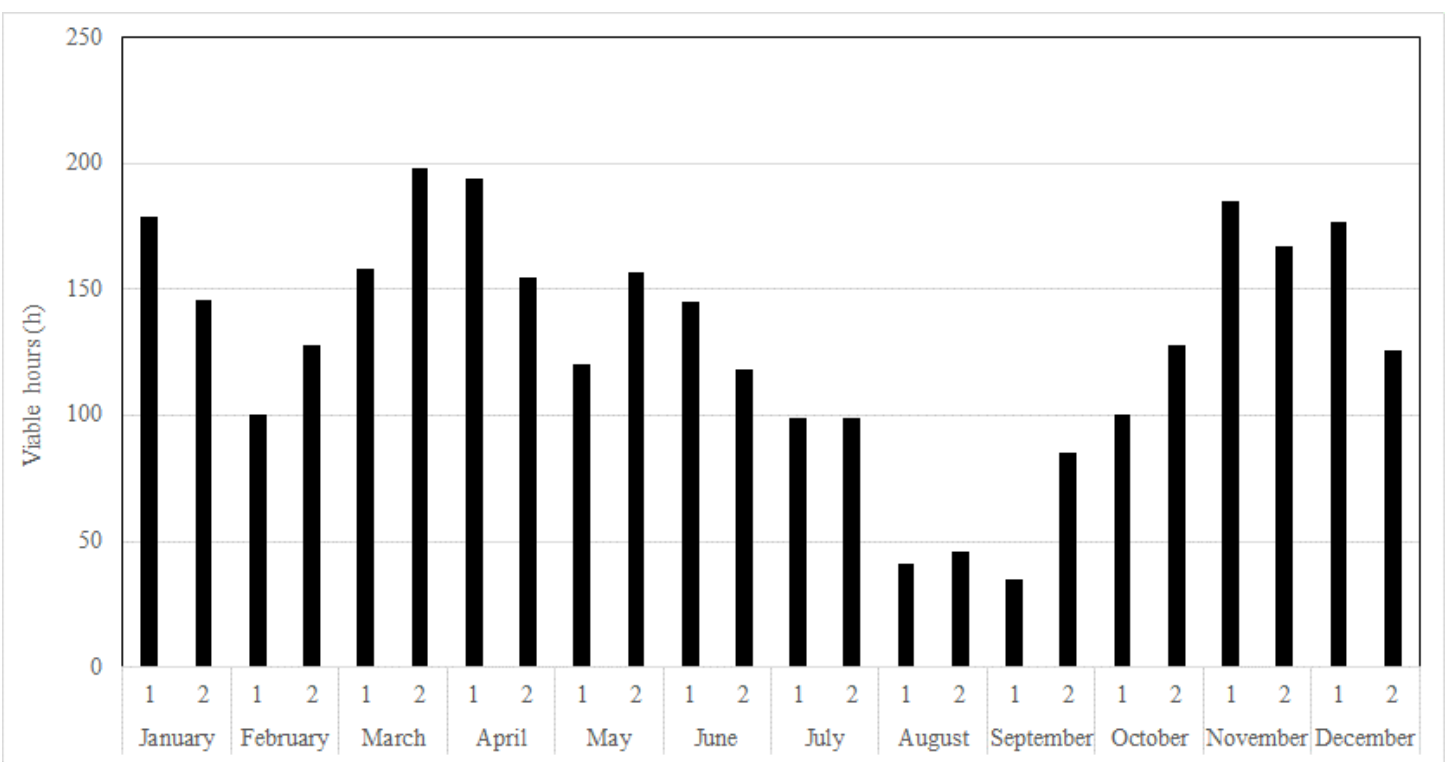

Figure 4. Total of viable hours in the first and second fortnights of each month of the year. Uberlandia-MG, Brazil.

The amount of viable hours by fortnight is a very useful value in setting the fleet for spraying. The number of machines is a function of the operational capacity and operational rhythm necessary to spray the area in a timely manner. This in turn depends on the volume of work and on the number of viable hours. Greater numbers of viable hours bring about the need for fewer machines.

\section{CONCLUSIONS}

The relative air humidity was the main restricting criterion for viable pesticide application windows, which are concentrated on average between 18:00 and 12:00 $\mathrm{h}$ in summer-autumn seasons, and between 24:00 and 9:00 $\mathrm{h}$ in winterspring seasons.

The number of viable hours varied from 35 $\mathrm{h}$ in the first half of September to $198 \mathrm{~h}$ in the second half of March, demonstrating a great variability in the application windows throughout the year, which makes the generic recommendations of spraying time inadequate if the month of the year is not considered.

\section{ACKNOWLEDGEMENTS}

To National Council of Scientific and Technological Development - CNPq and Research Foundation of the State of Minas Gerais FAPEMIG.

RESUMO: O sucesso das aplicações de produtos fitossanitários está condicionado às condições meteorológicas. Com este trabalho objetivou-se determinar as janelas de aplicação adequadas para a realização das aplicações de produtos fitossanitários, tendo como parâmetros a análise dos dados históricos da temperatura e umidade relativa do ar, velocidade do vento e ocorrência de chuva, para a região de Uberlândia-MG, no período de 2009 a 2014. Com o auxílio de uma planilha eletrônica, e tendo como parâmetro as condições meteorológicas ideais para a realização das aplicações de fitossanitários (temperatura abaixo de $30^{\circ} \mathrm{C}$, umidade relativa acima de $55 \%$, velocidade do vento entre 3 e $12 \mathrm{~km} \mathrm{~h}^{-1} \mathrm{e}$ dados de pluviosidade menores que $0,2 \mathrm{~mm} \mathrm{~h}^{-1}$ ), fez-se o cruzamento dos dados com o intuito de verificar em quais horas do dia as quatro condições climáticas estavam dentro dos intervalos recomendados para se ter uma melhor eficiência nas aplicações. De acordo com os resultados, pôde-se concluir que a umidade relativa do ar foi o critério principal de restrição para as janelas de aplicação, que estão concentradas, em média, entre as $18 \mathrm{~h}$ e $12 \mathrm{~h}$ no verão, e entre as $24 \mathrm{~h}$ e $9 \mathrm{~h}$ no inverno. O número de horas viáveis para uma boa aplicação variou de 35 na primeira quinzena de setembro a 198 na segunda quinzena de março, demonstrando a grande variabilidade das janelas de aplicação ao longo do ano, o que torna as recomendações genéricas de horário para pulverização inadequadas se não for levado em consideração o mês do ano.

PALAVRAS-CHAVE: Condições climáticas. Pulverização. Tecnologia de aplicação. 


\section{REFERENCES}

ALVARENGA, C. B.; TEIXEIRA, M. M.; ZOLNIER, S.; CECON, P. R.; SIQUEIRA, D. L.; RODRIGUES, D. E.; SASAKI, R. S.; RINALDI, P. C. N. Efeitos do déficit de pressão de vapor d'água no ar na pulverização hidropneumática em alvos artificiais. Bioscience Journal, Uberlândia, v. 30, n. 1, p. 182-193, 2014.

ANDEF - Associação Nacional de Defesa Vegetal. Manual de tecnologia de aplicação. São Paulo: Linea Creativa, 2004. 52 p.

ANTUNIASSI, U. R. Qualidade em tecnologia de aplicação de defensivos. In: CONGRESSO BRASILEIRO DE ALGODÃO, 5., 2005, Anais..., Salvador. Campina Grande: Embrapa, 2005. 6 p.

CARVAlHO, D. F.; OLIVEIRA, M. A. A.; SOUSA, S. A. V.; CARVALHO, P. O. L. Estimativas de ocorrência de veranicos em Seropédica, Vassouras e Piraí (RJ), e suas influências no rendimento da cultura do feijão (Phaseolus Vulgaris L.). Ciência e Agrotecnologia, Lavras, v. 23, n. 2, p. 323-330, 1999.

FRIEDRICH, T. Quality in pesticide application technology. In: RAETANO, C. G.; ANTUNIASSI, U. R. Qualidade em tecnologia de aplicação. Botucatu: Fepaf, 2004. p. 93-109.

HETZ, E.; SAAVEDRA, M.; VENEGAS, A.; LÓPEZ, M. Ventana de aplicación de plaguicidas en huertos de arándano (Vaccinium sp.) de la zona de Los Ángeles, Chile. Agricultura Técnica, Chillán, v. 64, n. 4, p. 1-17, 2004. http://dx.doi.org/10.4067/s0365-28072004000400006

INMET - Instituto Nacional de Meteorologia. Estações Automáticas. Disponível em: < http://www.inmet.gov.br/portal/index.php?r=estacoes/estacoesAutomaticas $>$. Acesso em: 29 de julho de 2015.

LADO, L. R.; SPARAOVEK, G.; VIDAL-TORRADO, P.; DOURADO-NETO, D.; MACIAS-VÁZQUEZ, F. Modelling air temperature for the state of São Paulo, Brazil. Scientia Agricola, São Paulo, v. 64, n. 5, p. 460467, 2007. http://dx.doi.org/10.1590/S0103-90162007000500002

MILAN, M. Gestão sistêmica e planejamento de máquinas agrícolas. 2004. 100 p. Tese (Livre- Docência) Escola Superior de Agricultura “Luiz de Queiroz”, Universidade de São Paulo, Piracicaba, 2004.

MINGUELA, J. V.; CUNHA, J. P. A. R. Manual de aplicação de produtos fitossanitários. Viçosa: Aprenda fácil, 2010. $588 \mathrm{p}$.

MURPHY, S. D.; MILLER, P. C. H.; PARKIN, C. S. The effect of boom section and nozzle configuration on the risk of spray drift. Journal of Agricultural Engineering Research, London, v. 75, n. 2, p. 127-137, 2000. http://dx.doi.org/10.1006/jaer.1999.0491

NUYTTENS, D.; SCHAMPHELEIRE, M.; BAETENS, K.; BRUSSELMAN, E.; DEKEYSER, D.; VERBOVEN, P. Drift from field crop sprayers using an integrated approach: results of a five-year study. Transactions of the ASABE, St. Joseph, v. 54, n. 2, p. 403-408, 2011. http://dx.doi.org/10.13031/2013.36442

NUYTTENS, D.; SCHAMPHELEIRE, M.; STEURBAUT, W.; BAETENS, K.; VERBOVEN, P.; NICOLAÏ, B.; RAMON, H.; SONCK, B. Experimental study of factors influencing the risk of drift from field sprayers, Part 1: Meteorological conditions. Aspects of Applied Biology, Cambridge, v. 77, n. 1, p. 321-329, 2006.

ROSA, A. G.; SCHIAVINI, I. Estrutura da comunidade arbórea em um remanescente florestal urbano (Parque do Sabiá, Uberlândia, MG). Bioscience Journal, Uberlândia, v. 22, n. 1, p. 151-162, 2006.

SANTOS, R. B.; SOUZA, A. P.; SILVA, A. C.; ALMEIDA, F. T.; ARANTES, K. R.; SIQUEIRA, J. L. Planejamento da pulverização de fungicidas em função das variáveis meteorológicas na região de SINOP MT. Global Science and Technology, Rio Verde, v. 6, n. 1, p. 72-88, 2013. 
SILVA, M. I. S.; GUIMARÃES, E. C.; TAVARES, M. Previsão da temperatura média mensal de Uberlândia, MG, com modelos de séries temporais. Revista Brasileira de Engenharia Agrícola e Ambiental, Campina Grande, v. 12, n. 5, p. 480-485, 2008. http://dx.doi.org/10.1590/s1415-43662008000500006 